\title{
The Lister Institute of Preventive Medicine: Seventy-fifth Anniversary of its Foundation
}

\author{
[From a Special Correspondent]
}

In 1889 a group of medical and scientific men,* impressed by the work of the Pasteur Institute in Paris, decided to try to set up an Institute in Britain for the investigation of infective disease in man and animals, and for the preparation of protective and curative materials for such diseases. They formed a committee under the chairmanship of Sir Joseph Lister, and in spite of the many doubts expressed proceeded to appeal for funds for this purpose. The general response was not encouraging, but the trustees of the will of a certain Mr. Beridge-who had left a large sum of money for the improvement of sanitary science-decided to contribute $£ 40,000$ to the proposed scheme.

On 25 July 1891, when about $£ 60,000$ had been subscribed, the "British Institute of Preventive Medicine" (as the Lister was then called) was incorporated as a limited liability company with the omission of the word "limited," to impress that the Institute was not established for the purpose of gain but for purely charitable and scientific objects.

At that time there was much hostility to scientific investigation in which experiments on animals were used. The plans for erect-

ing a building to house the Institute proceeded with much difficulty, and it was by no means certain that the committee would get the new building licensed for animal experiments. An amalgamation was therefore arranged with the College of State Medicine in Great Russell Street, Bloomsbury, which already had a licence and which could be transferred to the new building. Scientific work began in Bloomsbury in 1894 , but it was not until 1898 that the staff could move to the new building in the Chelsea Bridge Road. Also in 1894 the Institute began to undertake the preparation of therapeutic substances; at first, a farm was rented near Harrow, but later (in 1902) a small estate with racing stables was bought at Elstree.

The Institute had to rely for its income on its endowments and on money from the sale of vaccines and sera, and the financial situation became very precarious. In 1896 a sum of money, collected in memory of Jenner, was offered to the Institute. In accepting the gift it was agreed to change the name to "The Jenner Institute of Preventive Medicine." A few years later, however, this had to be given up, as a commercial organization had a prior claim to the name, which was therefore changed to "The Lister Institute of Preventive Medicine." No happier title could have been chosen, as Lister had interested himself in the project from the very beginning and had given unstintingly of his time in its foundation. In 1912 the late Lord Iveagh gave $£ 250,000$ to the Institute, and about the same time profits from sales improved-and this,

- Those men most prominent in the scheme were Lister, Horsley, Roscoe, Ray Lankester, Thomas Huxley, and Paget. coupled with a few substantial donations, provided sufficient income for the development of a modest and highly successful research and production institute.

In 1913 a proposal was put forward which, if it had been accepted, would have brought the Lister Institute as such to a close. The Government were considering the establishment of a department of medical research in accordance with the provisions of the National Insurance Act of 1911, and certain members of the Institute's governing body thought that the nation should be offered the organization and resources of the Institute as a nucleus of the new scheme. The proposal was hotly debated, and, while more people seemed to be in favour rather than against it, it was rejected by a poll held at a special meeting in 1914.

\section{Research and Teaching}

In addition to research, teaching was an important branch at first, but this was gradually discontinued as departments of bacteriology were established throughout Britain. In 1905 the Institute was admitted as a School of the University of [Barratts Photo Press London for the purpose of research, and this gave the opportunity for students to join the Institute and proceed to higher degrees in the University. The scientific staff has always been small, seldom more than 30 , but the number of workers has been swelled by those who came from the Dominions and elsewhere to take advantage of the exceptional facilities and training. that the Institute offers. The list of those who worked in the Institute is a long and impressive one, and many made finecontributions to their subjects: it includes a Nobel prizeman; many who have been elected to the Royal Society ; and others. who have received honours for their work on behalf of home or colonial governments. Though it would be invidious to select persons for special mention the name of Martin comes. to mind whenever the Lister is mentioned. Charles Martin (later Sir Charles) was appointed its director in 1903, and until his retirement in 1930 had a profound influence upon its. development, and was largely responsible for the high quality of its scientific work and the large number of scientists who. worked there.

\section{Notable Events}

In 1894 reports came from abroad of the successful use of diphtheria antitoxin prepared from horses. The Institute immediately undertook its preparation, but as there were no. stables in Great Russell Street the first horses for immunization were kept at the Brown Animal Institution (just south of the Thames) in the care of Sherrington, its professor superintendent. During the immunization Sherrington heard that his. 
young nephew was seriously ill with diphtheria. He immediately bled the horse, separated the serum, and injected it into his nephew with success. Sir Charles Sherrington appears to have been the first person to have used diphtheria antitoxin prepared in this country.

Three other important events may be cited. As early as 1909 a unit was set up to study the importance in scientific investigations of the statisical treatment of the results, and the head of the unit later became the first professor of epidemiology and vital statistics in the University of London. After the first war members of the nutrition department, together with workers from the Medical Research Council, spent three years in Vienna studying the rickets which had become prevalent in central Europe. Their investigations helped considerably in the eradication of this disease. In 1947 the Ministry of Health asked the Institute to undertake the preparation of dried plasma for transfusion and certain protein fractions of blood plasma (such as gammaglobulin for measles ; antihaemophilic globulin for haemophilia) for clinical use. These were to be prepared from blood collected by the National Blood Transfusion Service from voluntary blood donors.

These few instances show. that all through the 75 years the Institute has shown foresight and initiative. It has been able to take on special and by no means easy scientific tasks. It has earned the respect of other scientific workers and organizations, so that co-operation has always been easy. The Institute can be justly proud of the part it has played during the past 75 years in the expansion of the field of preventive medicine.

\section{CONFERENCES AND MEETINGS}

\section{International Congress of Agricultural Medicine}

The third international congress of agricultural medicine was held in Bratislava on 26-30 September.

Discussing the different serogroups and serotypes of leptospirosis, E. H. ToP (U.S.A.) pointed out that these vary considerably from country to country-for example, in the Mid-western section of the U.S.A. the leading pathogenic strain was Leptospira pomona. In America a new and increasingly common form of transmission of leptospirosis had arisen from the use of artificial farm pools for swimming. $F$. NizANSKy (Czechoslovakia) described several outbreaks of brucellosis in brucella-free cattle and pigs, which had been traced to infected manure in their environment. Another finding had been that some animals had been infected by their attendants, who were suffering from brucellosis.

\section{Tularaemia}

Several speakers from Czechos'ovakia read papers on tularaemia. Recalling that in 1937 the hare had been incriminated as the intermediary host in this disease, $\mathrm{Z}$. KozUSNIK stressed the importance of preventive inoculation of all persons at risk. K. POPEK considered that more emphasis should be laid
[From a SPECIAL CoRrespondent]

on the disease masquerading as one of the more common general infections, such as influenza and tonsillitis. He also stated that owing to more intensive methods of agriculture the rodent was to a large extent replacing the hare as the chief vector. Thus he had studied an outbreak of tularaemia in a sugar factory, in which the intermediary hosts had been found to be mice, which had established themselves in stacked sugar cane that had been left undisturbed for longer than usual. The factory employees had been infected by inhalation of this contaminated material.

\section{Toxicology}

W. WASSERMAN (Israel) emphasized that on the average $20 \%$ of crops in the emergent countries were lost owing to destruction by pests. Though pesticides conferred great benefits, scrupulous control was necessarya fact confirmed by K. UEDA (Japan), who, speaking specifically of parathion (which had been introduced in 1952 to combat rice-stem borer), pointed out that initially there had been 1,800 cases of poisoning. With stricter control, this had now been reduced to some 300 cases annually. Nevertheless, equaily efficacious, less toxic pesticides were now availab!e, and in his opinion the prohibition of the use of parathion was now indicated. The importance of the search for other nontoxic substitutes had also been demonstrated by the use of antibiotics obtained from streptomyces_blasticidin and kasugramycin -instead of mercury against rice blast. Three years after these had been introduced no case of mercury poisoning had been detected. The need for further advance was underlined by J. WAKATSUKI (Japan), who reported that a quarter of all farmers in the Nagano area, where mixed farming took place, had some symptoms of pesticide intoxication.

\section{Agricultural Accidents}

Discussing tractor accidents J. PielDESRUISSEAUX (France) spoke of deficient visibility from tractors as a causative factor, due mainly to the projection of bonnet and accessories and from the positioning of backside wheels and mudguards. He suggested that the recent advances in achieving better visibility from lorries should also be applied to tractors. L. W. KNAPP (U.S.A.) stated that in his country agriculture had the third highest actident rate. In 1964, 8,300 farmers had died as a result of accidents on the land, while a further 760,000 had suffered disabling injuries, which were often severeparticularly those due to machinery accidents.

\section{Sir Peter Medawar on Animal Experimentation}

The 35th Stephen Paget Memorial Lecture of the Research Defence Society was given by Sir Peter Medawar, F.R.S., Director of the National Institute for Medical Research, on 25 October at University College, London. Under the title "Animal Experimentation in a Large Research Institute" Sir Peter discussed the justification for the use of animals in enlarging medical knowledge. $\mathrm{He}$ considered it important both that medical scientists should defend their activities and that the general public should demand reassurance that medical research was properly conducted. These activities included not only trials on animals but also those on man, and the morality of keeping or not keeping people alive by the artificial contrivances now available. On the other hand, he considered that the upgrowth of ignorant sentimentality and the lack of humane understanding made the general public unqualified for the wardenship of animals used for research. The spate of literature personalizing animals, starting with Alice in Wonderland in 1865, had conditioned every child today.

\section{Humane Understanding}

Continuing, Sir Peter said that humane understanding had recently been deliberately fostered by the British Veterinary Association and the Animal Health Trust, particularly 